\title{
Reflections on A Hero Perished
}

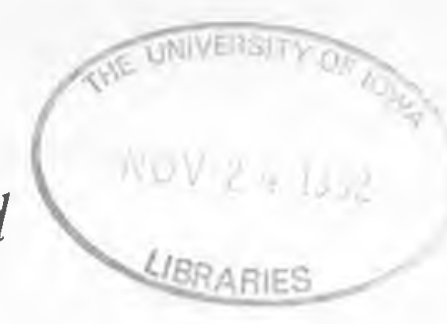

PAUL BAENDER

\section{A Hero Perished: The Diary and Selected}

Letters of Nile Kinnick (University of Iowa Press, 1991) began for me in October 1989. I happened to learn then from David Schoonover, Curator of Rare Books, that Special Collections at the University of Iowa Libraries held a Nile Kinnick Papers Collection. David showed me one of Kinnick's diary notebooks, and at once, with a fervor I still cannot altogether explain, I knew that here was something to do. Here was the prospect of a book by and about a man I had heard of with distant fascination in my California boyhood. I discovered that no one had done or done well what was obvious to do, a book presenting Kinnick in his own words and as what a latecomer might believe he turned out to be. Early in 1990, during my research, a man I met while checking Kinnick's citations at the local Christian Science Reading Room asked me why I was working on Kinnick. What he meant to ask, I gathered, was what an English professor, of all people, was up to. His legitimate question deserved a frank answer, and I said " $\mathrm{I}$ ' $\mathrm{m}$ doing it for the money." I was ashamed as soon as I said this. I knew I was putting him off with fake candor, and I hope he did not recognize that I was disguising a residual fascination through a venal motive that he and anybody else outside my head would understand if despise. Even walking-around money was nice to think of, but it would be only a happy byproduct. I also knew my motive could not be professional advancement, for I was a tenured professor nearing retirement who had reached an age when no work he might do would much affect his standing among his peers, except perhaps for the worse if it was something they thought beneath doing. But besides my interest and curiosity regarding Kinnick, I admit to 


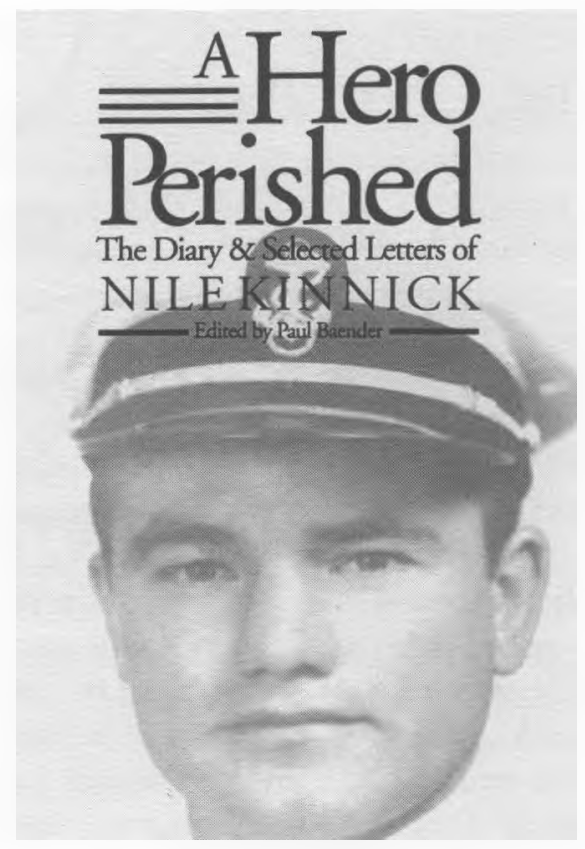

an attraction toward what looked to be an easy project after my involvement in several that had taken years. This would be a short maverick adventure with a subject novel but simple, and I would go at it one on one-no dependencies, no survival gear. I was wrong. The project turned out to be anything but easy, short, or simple; and it stretched my personal and professional resources to the point that I became a finely drawn wire indeed.

The book was in two basic ways unlike any other research project in my career. First, I often had to resort to living informants instead of a body of prior scholarship based on dead sources who could not talk back. For Kinnick such a body did not exist. Three family scrapbooks in the Kinnick Collection constituted an ample record, but I realized early that if my book was to consist largely of Kinnick's diary and letters, I would need more explanatory information. The sources would have 
to be people who had been there, who could identify persons and places and otherwise help develop the background of Kinnick's personal experience.

And so after I had read everything in the Collection, selected the letters to publish, and isolated crucial blank spots, I started looking for people. There was much flailing about, but I was fortunate in having a grapevine of contacts develop without my control. I happened to know people who put me on to others who, themselves useful, led me to still others who told me more than I knew enough to ask about. To locate friends of Kinnick who had long since left Iowa City or Iowa altogether, I frequently called on the mailing list of the Iowa Alumni Association, which led me to classmates from Puget Sound to Jacksonville, Florida. Where there was no local contact of any sort I could be frustrated, most notably in the case of Celia Peairs (now Mrs. Celia Peairs Fay), a significant woman for Kinnick from 1940 to the end of his life. Though a Des Moines native, she had not attended Iowa but did take a master's degree at the University of Chicago. I had wrongly assumed that Kinnick first met her in Iowa City though I knew from his correspondence that he visited her in Chicago in 1940 and 1941. I located her at last through the University of Chicago Alumni Association, as I should have done earlier.

There was a distinct pattern of response among my informants. Eager to help, many tended toward anecdotes, a few or just one, and toward descriptions of Kinnick in scenes where they too had been present as observers or active parties. And it did not matter whether they had known him well or hardly at all. One man who did not know him enough to speak to had sat next to him once at Whetstone's lunch counter in the spring of 1940. He recalls what Kinnick was wearing-jeans and a T-shirt-and that some guy walking past behind them put his hands on Kinnick's shoulders and said something like "How's it going, Mr. World?" End of story, extent of acquaintance. A woman who knew him rather well-his date after the College All-Star Game of 1940-recalls that he calmly handled the 
autograph seekers and the reporters and that he and she then went out to more than one Chicago nightclub.

The anecdotes were only occasionally relevant to the sort of book I envisioned. A valuable long article or short book, another project altogether, might be a collection of anecdotes about Kinnick in all his contexts. This would amount to a Cubist rendition, suggesting the idea of The Man Cut in Slices that intrigued Henry Miller, for the assembled stories are often incongruent and produce a flat, two-dimensional effect. What depth, what interior Kinnick, would one infer from a collection that told of his buying beer for himself and two friends in Omaha while they were all underage and next told of his ushering at the Christian Science church in Iowa City? ${ }^{1}$ Perhaps the most reliable general inference from such a gathering would be that Kinnick compartmentalized his experience and his acquaintances. Such a conclusion is already indicated in the instance of Judge William C. Stuart, one of my most generous and helpful informants. He was Kinnick's fraternity brother, and during Kinnick's year in law school they roomed together in the Iowa Law Commons. Kinnick once grouped him among his "closest friends." But though Judge Stuart has written a detailed reminiscence of the Kinnick he knew, he could not help me locate Celia Peairs. He had never heard of her. When I later told Mrs. Fay this, she said "I wonder where he thought Nile was going all those weekends." Not that Kinnick had anything to hide from him; he simply kept Celia in one niche and Bill in another.

The Kinnick letters his friends have donated to the Collection confirm this sense of him, though of course he might chat to one friend about the doings of others. Readers of $A$ Hero Perished will have noticed how oratorical and old-fashioned his prose frequently sounds in letters home. In writing to his

${ }^{1}$ Michael Kelly reports the beer anecdote in an article on $A$ Hero Perished (Omaha World-Herald, 27 October 1991), as told to him by Kinnick's friend at Benson High School, Ed Kiddoo. Many anecdotes about Kinnick and the 1939 football season are in Al Couppee, One Magic Year (n.p., 1989). For others see Scott M. Fisher, The Ironmen (Lincoln, 1989), and D.W. Stump, Kinnick: Man and Legend (lowa City, 1975). 
family, even to his younger brother George, he clicked into a cultural tradition that prized linguistic decorum and formal eloquence; only occasionally did he lapse into the vernacular. Readers may also have noticed that he sometimes repeated identifications of his friends to his parents, a tendency often demonstrated in letters omitted from the book. His friends were so distant in his global sense of his experience that he thought his parents might not remember them from previous introductions. On the other hand, letters to Jim George, Bob Hobbs, Erwin Prasse, and others-donated too late to include in the book - have different styles and tones, and these vary somewhat from one correspondent to another. In writing to Jim George, Kinnick entered their niche, another ethos with its own circle of familiar names, memories, and concerns; and his prose accordingly became casual, at ease in another continuing conversation. In one place he parodied his formal style when humorously claiming hurt feelings; in the same letter, when after mentioning the war he began his oratorical manner, he realized that he was mounting a soapbox for the wrong person, offered a disclaimer - "I am not sermonizing but just imparting a thought" - and returned to informality.

Adaptability of this sort implies receptivity. Kinnick was "all there" for his parents, his brothers, his grandmother, and his friends. Nobody got the brushoff; to everyone who knew him he seemed attentive, deferential, and warm. Nor does he appear to have approached a receptive limit; as his death date neared he recorded in his diary a mass of incidental impressions from the big new world of an ocean environment, with its flying fishes and its Trinidad. And so anyone proposing a Kinnick biography should keep two cautions in mind. First, discovery of more Kinnick letters outside the family may reveal a still broader sensibility and a more complicated character than we now know. Second, had he lived, he might have gone on to amass impressions and acquaintances, with an attendant diffusion of his attitudes, throughout a long life. Though he evinced strong basic tendencies, such as ambition and nostalgia, the ultimate contours he might have put upon his experi- 
ence must therefore be left to speculation. Possibly an expanded receptivity would have delayed his integration to the point that he became a social and political butterfly, yet his principles of economic and racial equity seemed unchangeable. No one can say what would have happened when such a man dies at twenty-four.

The other unique feature of the Kinnick project was that I had no critical tradition to join, or rather none that I cared to join. Several ama-

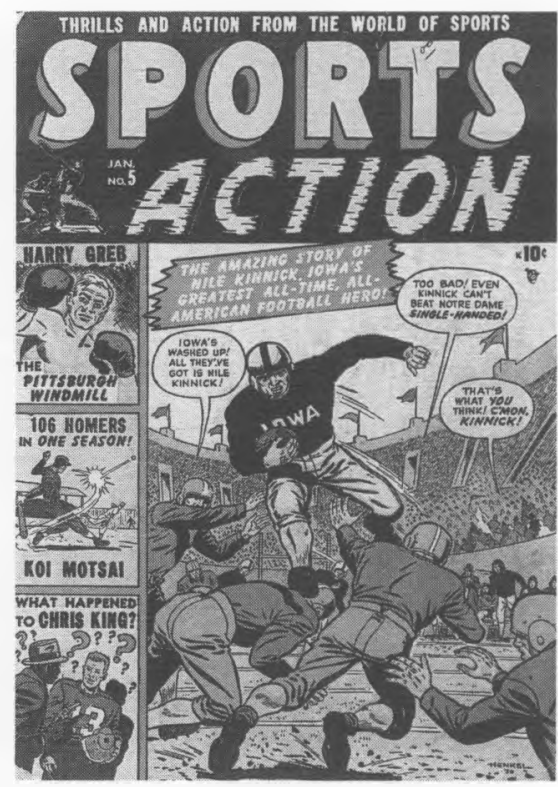
teur pieces have contributed obscure facts unavailable without their help, and that is good, but their common hero worship has been naive to the extent of misrepresentation. As a body they have manufactured a sappy paragon that in life would be a bore and that Kinnick never was or tried to be. The culmination of this tradition was reached early, in "The

Nile Kinnick Story," a 1951 comic book feature. ${ }^{2}$ The story line was a sort of trompe l'oeil: how many errors can you spot in these pictures? Among them, Kinnick supposedly caught a scoring pass that allowed Iowa to come from behind against Notre Dame in 1939 (two errors); he supposedly strafed a Japanese airfield in the Pacific and later crashed when running out of fuel after a dangerous secret mission (at least four errors); and many more. Kinnick's Topps football card of 1955 likewise read that he crashed while "on a mission." 3 The

\footnotetext{
${ }^{2}$ The story was in Sports Action No. 5 (January 1951); copy donated to the Kinnick Collection by John Rankin McLure.

${ }^{3}$ Card donated to the Kinnick Collection by William C. Stuart. It was No. 6 in the Topps "All-American" series. All known specimens render Kinnick's first name as
} 


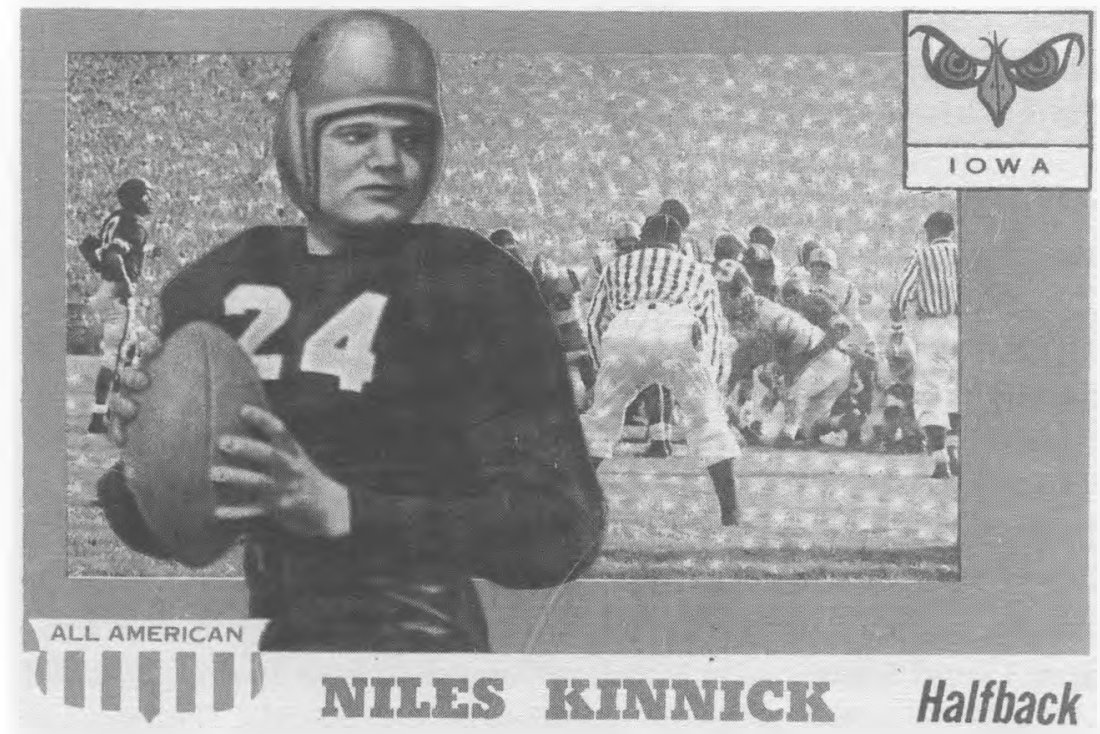

best retrospective-aside from my introduction to $A$ Hero Perished, for what it is worth-has been Ron Fimrite's profile in Sports Illustrated, a companion piece to his later profile of Hobey Baker of Princeton, an eerily similar football hero-pilot of the World War I era. ${ }^{4}$ The critical tradition from which Fimrite wrote seems to have been what one associates with New Yorker profiles, notable for responsible if not exhaustive research, sympathetic but not beguiled accounts, and a clean, impersonal style-altogether professional journalism of a high order.

How then was $I$ to manage what I learned about Kinnick and his times? It had been one thing to fantasize beforehand about going one on one with my subject, but now that I was alone with it, I wanted survival gear after all. In my isolation I endured moments of false shame when I felt like an intruder.

\footnotetext{
"Niles."

4"Nile Kinnick," Sports Illustrated 67, no. 9 (31 August 1987):112-24; "A Flame that Burned Too Brightly," Sports Illustrated 74, no. 10 (18 March 1991):78-90.
} 
I was from California, not Iowa, not the midwest, and I was only an impoverished kid when Kinnick did those remarkable things, knew so many people, and wrote all those letters. Who was I even now to assume a custodial role over his written remains and to beg the familiarity of writing an intimate introduction?

But in the meantime, to my amazement, people were trusting me with all manner of privileged information. Some of them were people I had just met, and others I have still never seen. It was as though I had barged in on a gathering, and instead of throwing me out, they wanted and therefore expected someone or assumed that I deserved a place since I chose to come in. And I think it was in good part this hospitality of so many-from Bob McCown to Jim Mitchell, from David Schoonover and Earl Rogers to Ray Bywater and Ed McCollister-that made a dereliction impossible. They were my survival gear. I could only be what they trusted me to be, somebody who would try to do right by the subject we all had in common. The only way I knew how was to meet the demands of the structure I had planned from the start: to represent Kinnick accurately in his texts and faithfully in whatever I wrote about him. Which is to say, I would behave as I had tried to in my previous work.

In my other historical studies I had always tried to induce understandings that related to the past not through prejudgments of our superiority or inferiority to it but through an arrest of attention, a sense of "so that's how it was!" Make of the past what we later chose, we would at bottom least have to recognize that it was itself and not another thing. In this instance the past itself, Nile Kinnick, was to do most of the talking, especially appropriate in his case because he was a prolific correspondent. And what he wrote would serve as a reliable entry into his character because the many extant letters allowed his enduring tendencies and developing convictions to show sharply to anyone who read them all and who could then select typically. My job was merely to establish contexts and to 
add explanations that might make the letters and diary fully intelligible. I was not to butt in with judgmental interpretations and chatty stories.

These were the rules I set for the letters and diary, but the introduction, which I saved for last, was another matter. After an obligatory biographical synopsis, it was to present as close and penetrating a profile as I could devise. Paul Zimmer, Director of the University of Iowa Press, made it very clear that this portion would be crucial in an assessment of my manuscript for publication. The project might stand or fall, and never in my professional life have I felt so humble and scared as when I launched into that profile. I had arranged the biographical account so as to lead into the profile where I thought bestwith a discussion of Kinnick's training in purposiveness - and from long mulling over I knew what else would have to be brought in. I had passed through the false shame. Though I nevertheless felt I was flying by instruments, I knew I had noticed true stresses of his character. I am unable to tell whether in representing Kinnick I also represented parts of myself, a Tom I had known in California, a Dick I had read about in a novel, and a Harry from who knows where. If I did, I believe a likely explanatory factor was a common wash of human variables among the lot of us.

But in the last paragraph of the profile I deliberately put together what I knew of Kinnick with some things I had learned elsewhere, for they matched by similarity and by contrast. I asserted there that Kinnick became "a familiar American man of a type manifested in every generation and in every region." I went on to characterize this American man both as strongly nostalgic and as yearning for a future glamor beyond actual successes. I called this condition a "psychic limbo," by which I meant an oscillation backward and forward in temporal orientation such that an individual might lose practical control of his present. I had often observed this configuration during an extensive project I put aside to do the Kinnick book, and I had been reminded in that earlier connection of Erwin Panofsky's "Titian's Allegory of Prudence," one of 
my old favorites from graduate school days and still to my mind a great article in the history of ideas. Panofsky conducted a historical exegesis of a Titian painting from the late sixteenth century, an elaborate emblem representing two tripartite groups: above, the heads of an old man facing left (toward the past), a middle-aged man facing front (toward the present), and a young man facing right (toward the future); below these, a corresponding wolf's head facing left, a lion's facing front, and a dog's facing right. Across the top, above the human heads, is a Latin motto: "ex praeterito praesens prudenter acit ni futura actione deturpet" (from the past the present acts prudently lest it spoil future action). There are several prints in Panofsky's Meaning in the Visual Arts exemplifying each group, for the humans beginning in the middle ages. The animal group had a still longer history, back to the ancient cult of Serapis. ${ }^{5}$

Titian's representation of the human figures implied a twogeneration educational sequence (and by extension an ongoing sequence) as well as a behavioral model for individual lives. The latter aspect was especially relevant to the conclusion of my Kinnick profile. He had lived long enough to enact a deviation from the efficient integrity of the prudential model, although from the very fact that the device recurred over several centuries one may infer that it was always an ideal necessary to admonish other cultures deviating in their own persistent ways. Kinnick was far from loss of practical control in an extreme of deviation, but I believe I did right to have the emblem in mind, for the behavioral ideal in that old template enabled me to particularize him in what I knew were American ways. He who had been a public model in his own time became an exemplar of another sort against a backdrop from the ages.

5"Titian's Allegory of Prudence: A Postscript"; collected in Erwin Panofsky, Meaning in the Visual Arts (Garden City: Doubleday \& Company, 1955), pp. 146-68. The obverse of an unofficial Massachusetts copper dated 1776 also has a triple human-head device, again in the left-front-right dispositions. The coin is much later than the latest item cited by Panofsky, who lists no American examples. See R.S. Yeoman, A Guide Book of United States Coins, 43rd ed. (Racine: Whitman Publishing Company, 1990), p. 35. 
But I come away from A Hero Perished with the sense of a job not fully done and never to be done, at least not by me. I must have missed informants with important stories to tell, and not much time remains to find them. Ideally a staff with ample funding should mount a Kinnick letter and data search nationwide, but just mentioning such a plan exposes its practical absurdity. One body of information most important to an understanding of Kinnick's family life is gone forever. This is the letters his mother Frances Kinnick sent him over the years following his departure for the University of Iowa. She destroyed them all after his death, thus leaving largely for speculation the nature of a mother-son relation when the mother was also the son's priest. And living in Iowa City, I have frequent reminders of my distance from Kinnick and his time here. The Ensley house at 530 North Dubuque Street, where he roomed with Jim George, has been replaced by one of the apartment buildings of pseudo-mansard roof design that have mushroomed on the east side in recent years. Racine's, the Mayflower, Ken and Fern's, and many other places are long gone. The old Phi Kappa Psi annex on Brown Street still stands, and I live only a long block from the former Delta Gamma sorority house at Summit and College, where Kinnick went to parties and came to pick up dates. I walk past that house on my way to campus, and I have thought of knocking at the door and asking permission to see the room where Kinnick danced with Era Haupert in the Fall of 1938. But that would be clinging to shadows; and I don't know what room it was. 